\title{
Anatomic variation of the facial artery and its implications for facial surgery: a case report
}

\author{
Cardinot, TM. ${ }^{1}$, , Vasconcellos, HA. ${ }^{2}$, Vasconcellos, PHB. ${ }^{3}$, \\ Oliveira, JR. ${ }^{4}$, Siqueira, PB. ${ }^{5}$ and Aragão, AHBM. ${ }^{6}$
}

\author{
${ }^{1}$ Associate Professor of Human Anatomy, Doctor in Science (D.Sc.), \\ Rural Federal University of Rio de Janeiro - UFRRJ, CEP 23890-000, Seropédica, RJ, Brasil \\ ${ }^{2}$ Associate Professor of Human Anatomy, Doctor in Science (D.Sc.), Medical Doctor (M.D.), \\ Petrópolis Medical College - FASE/RJ, CEP 25680-120, Petrópolis, RJ, Brasil \\ ${ }^{3}$ Surgeon of the Vascular Surgery Service, Medical Doctor (M.D.), Andaraí Federal Hospital, \\ CEP 20541-170, Rio de Janeiro, RJ, Brasil \\ ${ }^{4}$ Professor of Anatomy, Postgraduated in Morphology, Grande Rio University - UNIGRANRIO, \\ CEP 25071-202, Duque de Caxias, RJ, Brasil \\ ${ }^{5}$ Graduation student in Biology Sciences, Rural Federal University of Rio de Janeiro - UFRRJ, \\ CEP 23890-000, Seropédica, RJ, Brasil \\ ${ }^{6}$ Assistant Professor of Anatomy, Master in Medicine (M.Sc.), Medical Doctor (M.D.), \\ State University of Rio de Janeiro - UERJ, CEP 20551-030, Rio de Janeiro, RJ, Brasil \\ *E-mail: tcardinot@yahoo.com
}

\begin{abstract}
Introduction: Vascular variations are congenital morphological differences that arise in the human body. Although, for the most part, do not cause injury to the individual, may be important in cases where it is necessary a specific access to the vascular system. The anatomic understanding of the facial artery and its branches are especially important in the practice of medical and dental care, in the surgeries of neck and face; and also for the radiologist to understand and interpret facial artery imaging when undertaking head angiography. The variations found in the formation and trajectories of the facial artery are described, however in the case studied, we described a morphological aspect until then not documented. In this sense, the objective of this study was to report a variation of the facial artery and to analyze it in relation to the literature state of the art. Case Report: During a head dissection of an adult male human cadaver fixed in 10\% formaldehyde we identified a variation of the facial artery branches. We reported, in the right hemiface, a supernumerary branch of the facial artery emerged between the origins of submentual and inferior lip arteries, close to the bottom edge of the mandible body, going towards the infra-orbital region. Discussion: The report of a considerable caliber atypical branching of the facial artery deserves attention because of the large number of interventions in this region, not only in cases of trauma, but also in cases of elective surgeries of face pathologies.
\end{abstract}

Keywords: facial artery, anatomic variation, vascular variation, vascular surgery.

\section{Introduction}

Vascular variations are congenital morphological differences that arise in the human body. Although, for the most part, do not cause injury to the individual, may be important in cases where it is necessary a specific access to the vascular system. It is very important for surgeons to know the exact frequency and variations of the arteries in the areas where they have to operate on (DI DIO, 1999).

The anatomic understanding of the facial artery and its branches are especially important in the practice of medical and dental care, in the surgeries of neck and face; and also for the radiologist to understand and interpret facial artery imaging when undertaking head angiography. Moreover, anatomical information on the head and neck arteries is important for less invasive treatment of diseases in those regions. In general, knowledge of angioarchitecture contributes to skillful segmentectomies, helping to preserve tissue, perform better surgery, and reduce both anesthesia and hemorrhage (HOLLINSHEAD, 1982; KRUGER, 1984).
The facial artery normally arises from the external carotid artery, just above the lingual artery, at the level of greater cornu of hyoid bone in the carotid triangle. It then passes upwards and forwards medial to the ramus of the mandible. It passes deep to the superficial part of the submandibular salivary gland making a characteristic loop, winds around the base of the mandible to enter the face at anteroinferior angle of the masseter muscle. In the face, it runs upwards and forward, laterals to angle of the mouth, and terminates as angular artery at medial angle of eye. Its branches in the face include: inferior labial artery, to the lower lip; superior labial artery, to the upper lip; lateral nasal artery, to supply the ala and dorsum of the nose (STANDRING, 2008).

The reported variations of the facial artery include: its intra parotid origin (NAYAK, 2006); arising as a common trunk with the lingual artery as linguofacial trunk (MIDY, MAURUC, VERGNES et al., 1986); its function being taken over by maxillary artery, transverse facial artery or the nasal branch of ophthalmic artery when absent 
(BERGMAN, THOMPSON, AFIFI et al., 1988); its termination as submental artery, labial artery or lateral nasal artery (BERGMAN, THOMPSON, AFIFI et al., 1988); and, a case of duplex artery ( $\mathrm{KOH}, \mathrm{KIM}, \mathrm{OH}$ et al., 2003).

However, in the case studied, we noticed a morphological aspect until then not documented. In this sense, the objective of this study was to report a variation of the facial artery and to analyze it in relation to the literature state of the art. The present case may provide useful information in different fields of oral and maxillofacial surgery.

\section{Case Report}

We used donated and unclaimed dead bodies for the purpose of medical education and research from the collection of the Department of Anatomy, State University of Rio de Janeiro, Brazil. The study involved the head and neck dissection of an adult male human cadaver fixed in 10\% formaldehyde. The dissection was made by planes and it was identified a variation of the facial artery branches. We reported, in the right hemiface, a supernumerary branch of the facial artery emerged between the origins of submentual and inferior lip arteries, close to the bottom edge of the mandible body (Figures 1 and 2).

\section{Discussion}

The arterial supply to the face is based on three main arterial trunks: the facial, transverse facial, and infraorbital arteries. The facial artery is usually the largest and dominant artery and plays a major role in supplying blood to the face (LASJAUNIAS, BERENSTEIN and DOYON, 1979). However, there are huge variations in its size and its extent between different individuals and even between different sides of the face ( $\mathrm{KOH}, \mathrm{KIM}, \mathrm{OH}$ et al., 2003). The anatomic study of the facial artery and its branches has two important aspects of interest: first, surgical anatomy in plastic and reparative surgery of the face and lip in cases of trauma and congenital malformation (PICCIONE, MANGANARO and ALMONY, 2010; ASAHINA, SAKAKIDARA, MIYASHIN et al., 1997), and in the surgery of malignant disease (PARRETT, PRZYLECKI and SINGER, 2012); second, radiological anatomy in the treatment of certain facial tumors by embolization procedures and in cases of facial reconstruction in plastic surgery (FURUKAWA, MATHES and ANZAI, 2013; FORBES, EARNEST, JACKSON et al., 1986).

The facial artery is extensively used in facial surgery as a pedicle in a number of flaps, such as nasolabial skin flaps (WEE, HRUZA and MUSTOE, 1990), oral mucosal flaps (RAYNER, 1984), buccal mucosal flaps (TEZEL, 2002), and more recently, facial artery musculomucosal flaps (XIE, LAVIGNE, RAHAL et al., 2013); and is also a crucial anatomic structure in other types of facial surgery, such as rhinoplasty and orofacial surgery (AROSARENA, 2007). As such, the facial artery has been extensively studied. The successful design and execution of flaps to reconstruct defects encountered in the midface is dependent on a thorough understanding of the location and the
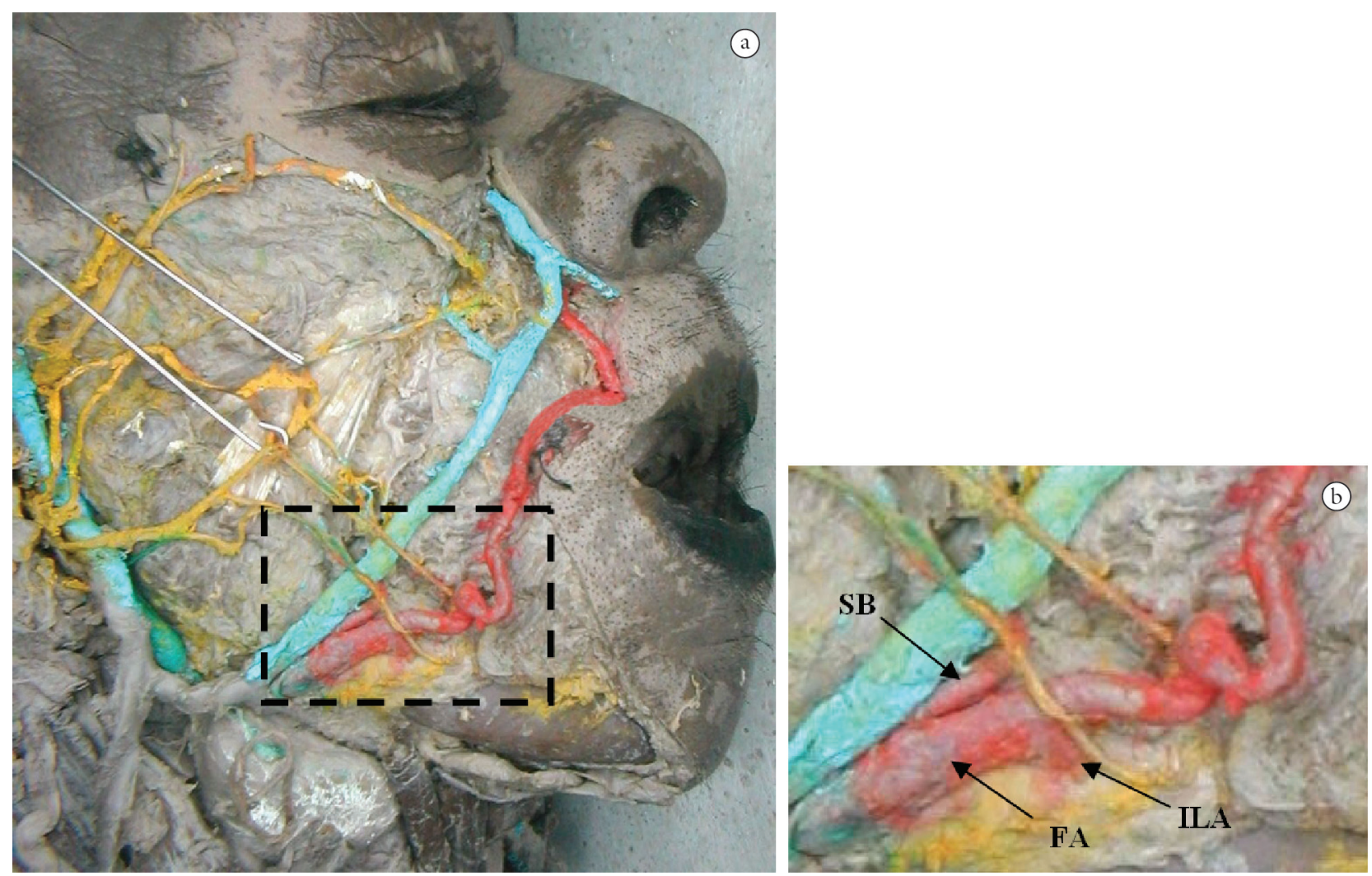

Figure 1. a) Overview picture of the dissection of a right human hemiface. b) Close-up view picture of the selected area showing a supernumerary branch (SB) of the facial artery (FA) emerged between the origins of submentual (SA) and inferior lip arteries (ILA), close to the bottom edge of the mandible body. 


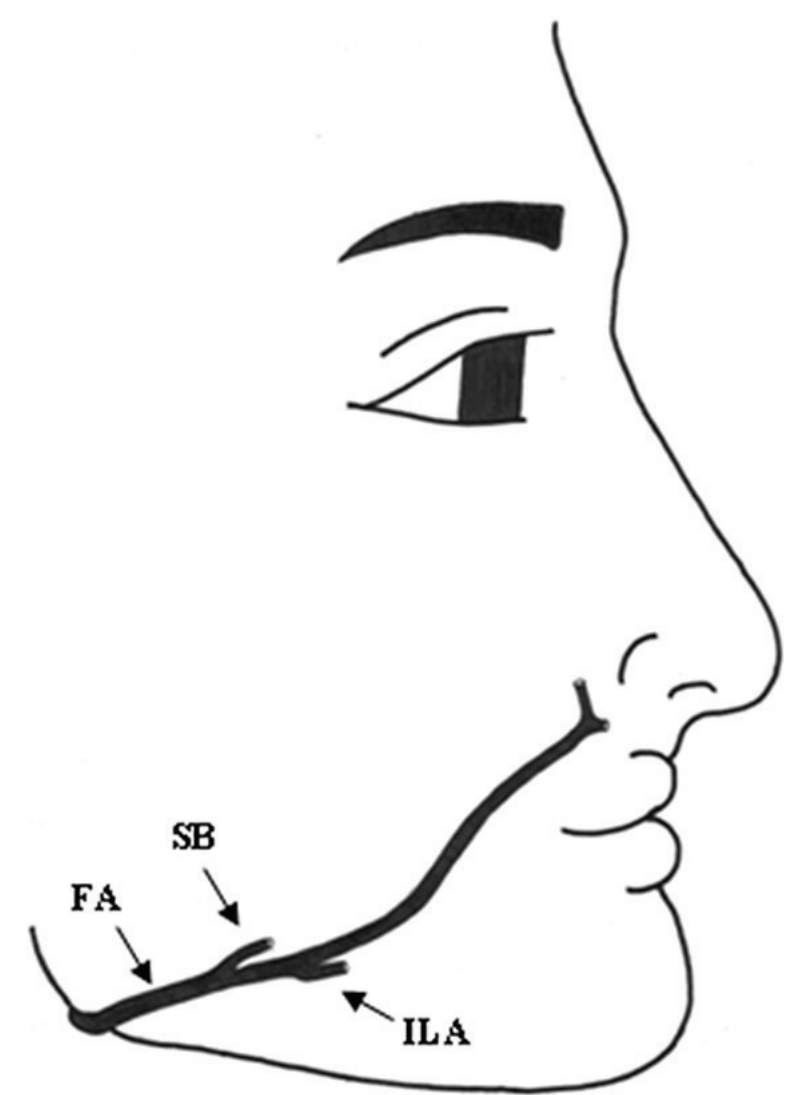

Figure 2. Schematic drawing of Figure 1 showing a supernumerary branch $(\mathrm{SB})$ of the facial artery (FA) emerged between the origins of submentual (SA) and inferior lip arteries (ILA), close to the bottom edge of the mandible body.

variations observed in facial artery anatomy (NIRANJAN, 1988; MITZ, RICBOURG and LASSAU, 1973). The reconstruction of lip defects using the abbe flap and other lip flap procedures involves surgical manipulation of one of the major branches of the facial artery, specifically the superior labial artery (MOMOH, KELLEY, DIAZ-GARCIA et al., 2013; PRIBAZ, MEARA, WRIGHT et al., 2000).

The facial artery ascends along the side of the mouth and nose and terminates at the medial palpebral commissure, where it joins the dorsal nasal branch of the ophthalmic artery. The facial artery is shown to give off two major branches near the oral commissure: the superior labial artery and the lateral nasal artery (the latter terminating as the angular artery). In addition, this angular artery is depicted to be of significant size. However, cadaveric studies have demonstrated significant anatomical variations in the course of the facial artery, especially distal to the oral commissure (LOUKAS, HULLETT, LOUIS JUNIOR et al., 2006; PINAR, BILGE and GOVSA, 2005; NAKAJIMA, IMANISHI and AISO, 2002). In this sense, our report of a considerable caliber atypical branching of the facial artery deserves attention. But in our case, the supernumerary branch arises proximally to the oral commissure instead of distally as described by many authors.

Many authors have attempted to describe the facial artery termination and its clinical and surgical importance.
According to a study of 40 facial arteries by Midy, Mauruc, Vergnes et al. (1986), the facial artery has terminated as angular artery in $27.5 \%$ cases, labial (superior) in $40 \%$, nasal in $30 \%$ cases and abortive artery in only one case. When the facial artery terminated before reaching the lower lip, it has been called abortive artery (MIDY, MAURUC, VERGNES et al., 1986). Examination of 284 hemifaces by Loukas, Hullett, Louis Junior et al. (2006) showed five types of facial artery termination labeled "A" through "E". Type A (135 cases, 47.5\%): facial artery terminated by bifurcating into superior labial artery and lateral nasal; type B $(110,38.7 \%)$ : facial artery terminating as superior labial artery and lateral nasal and lateral nasal continuing as superior alar artery; type C $(24,8.4 \%)$ : facial artery terminating as superior labial artery; type D (11,3.8\%): facial artery ending as superior alar artery; type E (4, 1.4\%): facial artery terminating as a rudimentary twig without providing any significant branches (LOUKAS, HULLETT, LOUIS JUNIOR et al., 2006). Koh, Kim, Oh et al. (2003) studied the topography and the course of the facial artery in 91 faces of 47 Korean cadavers. Thirty-three of the specimens were male and 14 were female, with an average age of 56 years (ranging 18-94 years). They reported that the final branch of the facial artery was the lateral nasal branch in $44.0 \%$ whereas it was the angular branch in $36.3 \%$ of the cases. In $54.5 \%$ of the cases, the facial artery ended symmetrically. They found no difference in the distribution pattern of the facial artery according to age or sex (KOH, KIM, OH et al., 2003). The facial artery termination in our case may be considered similar to the nasal termination described by Midy, Mauruc, Vergnes et al. (1986) and Koh, Kim, Oh et al. (2003) and Type A of Loukas, Hullett, Louis Junior et al. (2006) study. Because a previous dissection of the other side of the face did not preserved the vasculature we don't have any information about the symmetries described by Koh, Kim, Oh et al. (2003).

Some authors reported facial artery branching variations. Marx, Kumar, Reddy et al. (2008) described bilateral anomalous facial artery. The right facial artery taking origin from the external carotid artery did not make any loop in the submandibular region, entered the face by winding round the lower border of mandible, and terminated as the inferior labial artery. The upper part of the right side face in this case was supplied by various branches of transverse facial artery, infra orbital artery and dorsal nasal artery. The origin, course and branching pattern of the left facial artery was normal except the inferior labial artery was missing from it. This case may be considered similar to the Type E of the Loukas, Hullett, Louis Junior et al. (2006) study, the difference being in their case the facial artery is providing branches to the lower lip (MARX, KUMAR, REDDY et al., 2008; LOUKAS, HULLETT, LOUIS JUNIOR et al., 2006). Lohn, Penn, Norton et al. (2011) studied the course of the facial artery and vein, branching patterns, terminations, and anomalous variants. Cadaveric dissections of 201 facial arteries were performed. All branches originated from a single facial arterial trunk in $86 \%$ of specimens and branching patterns were symmetrical in $53 \%$. The facial artery predominantly terminated as a lateral nasal artery (49\%). In 5 cases, the facial artery was undetectable with transverse facial arterial dominance ( 1 case bilateral). Facial arterial dominance in facial blood supply is common but unpredictable (LOHN, 
PENN, NORTON et al., 2011). Although many facial artery branching previous descriptions, we reported a variation not yet described: in the right hemiface, a supernumerary branch of the facial artery emerged between the origins of submentual and inferior lip arteries, close to the bottom edge of the mandible body. Unfortunately, it was not possible to describe its course and possible branches. Because this material was for medical education purpose, when we noticed this variation most part of the facial arteries branches have already been dissected improperly.

Our anatomical variation report, as well as many anatomical variations described in the literature, can impact the surgeon's ability to use certain local flaps and, with the advent of facial transplantation, may become important for the development of subunit transplantation. Although there is significant disagreement among the findings in the published cadaveric studies as to the distribution and the frequency of variations in facial artery anatomy, there is broad agreement that anatomical variation is the rule rather than the exception. These studies have also demonstrated the need for a noninvasive in vivo technique of evaluating facial artery anatomy to facilitate preoperative planning in complex facial reconstructions.

\section{References}

AROSARENA, OA. Cleft Lip and Palate. Otolaryngologic Clinics of North America, 2007, vol. 40, n. 1, p. 27-60. PMid:17346560. http://dx.doi.org/10.1016/j.otc.2006.10.011

ASAHINA, I., SAKAKIDARA, T., MIYASHIN, M., TACHIKAWA, $\mathrm{N}$. and ENOMOTO, S. Congenital Midline Sinus of the Upper Lip: Case Report and Review of Literature. Cleft PalateCraniofacial Journal, 1997, vol. 34, n. 1, p. 83-85. http://dx.doi. org/10.1597/1545-1569(1997)034<0083:CMSOTU>2.3.CO;2

BERGMAN, RA., THOMPSON, S., AFIFI, A. and SAADEH, F. Compendium of human anatomic variation. Munich: Urban \& Schwarzenberg Baltimore, 1988.

DI DIO, LJ. The importance of anatomy. Annals of Anatomy, 1999, vol. 181, n. 5, p. 455-465. http://dx.doi.org/10.1016/S09409602(99)80024-7

FORBES, G., EARNEST, F., JACKSON, IT., MARSH, WR., JACK, CR. and CROSS, SA. Therapeutic Embolization Angiography for Extra-Axial Lesions in the Head. Mayo Clinic proceedings. Mayo Clinic, 1986, vol. 61, n. 6, p. 427-441. http://dx.doi. org/10.1016/S0025-6196(12)61976-4

FURUKAWA, M., MATHES, DW. and ANZAI, Y. Evaluation of the facial artery on computed tomographic angiography using 64-slice multidetector computed tomography: implications for facial reconstruction in plastic surgery. Plastic and Reconstructive Surgery, 2013, vol. 131, n. 3, p. 526-535. PMid:23446566. http:// dx.doi.org/10.1097/PRS.0b013e31827c6f18

HOLLINSHEAD, WH. Anatomy for Surgeons: Head and Neck. JB Lippincott, 1982.

$\mathrm{KOH}, \mathrm{KS}$. KIM, HJ., OH, CS. and CHUNG, IH. Branching patterns and symmetry of the course of the facial artery in Koreans. International Journal of Oral \& Maxillofacial Surgery, 2003, vol. 32, n. 4, p. 414-418. PMid:14505627. http://dx.doi. org/10.1054/ijom.2002.0372

KRUGER, GO. Cirurgia Bucal e Maxilo-Facial. 5th ed. Rio de Janeiro: Guanabara Koogan, 1984.
LASJAUnias, P., BERENSTEIN, A. and DOYON, D. Normal functional anatomy of the facial artery. Radiology, 1979, vol. 133, n. 3 Pt 1, p. 631-638.

LOHN, JW., PENN, JW., NORTON, J. and BUTLER, PE. The course and variation of the facial artery and vein: implications for facial transplantation and facial surgery. Annals of Plastic Surgery, 2011, vol. 67, n. 2, p. 184-188. PMid:21712695. http:// dx.doi.org/10.1097/SAP.0b013e31822484ae

LOUKAS, M., HULLETT, J., LOUIS JUNIOR, RG., KAPOS, T., KNIGHT, J., NAGY, R. and MARYCZ, D. A detailed observation of variations of the facial artery, with emphasis on the superior labial artery. Surgical and Radiologic Anatomy, 2006, vol. 28, n. 3, p. 316-324. PMid:16547605. http://dx.doi.org/10.1007/ s00276-006-0093-0

MARX, C., KUMAR, P., REDDY, S. and VOLLALA, VR. Bilateral variation of facial artery: a case report. Romanian Journal of Morphology and Embryology, 2008, vol. 49, n. 3, p. 399-401. PMid:18758647.

MIDY, D., MAURUC, B., VERGNES, P. and CALIOT, P. A contribution to the study of the facial artery, its branches and anastomoses; application to the anatomic vascular bases of facial flaps. Surgical and Radiologic Anatomy, 1986, vol. 8, n. 2, p. 99107. PMid:3097857. http://dx.doi.org/10.1007/BF02421376

MITZ, V., RICBOURG, B. and LASSAU, JP. [Facial branches of the facial artery in adults. Typology, variations and respective cutaneous areas]. Annales de Chirurgie Plastique Esthétique, 1973, vol. 18, n. 4, p. 339-350. PMid:4775922.

MOMOH, AO., KELLEY, BP., DIAZ-GARCIA, RJ., KULKARNI, AR., KOZLOW, JH., BULLOCKS, JM. and LEE, BT. An alternative mucosal flap for nasal lining: the superior labial artery mucosal flapan anatomic study. Journal of Craniofacial Surgery, 2013, vol. 24, n. 2, p. 626-628. PMid:23524761. http://dx.doi.org/10.1097/ SCS.0b013e318280206c

NAKAJIMA, H., IMANISHI, N. and AISO, S. Facial artery in the upper lip and nose: anatomy and a clinical application. Plastic and Reconstructive Surgery, 2002, vol. 109, n. 3, p. 855-861; discussion 862-853.

NAYAK, S. Abnormal intra-parotid origin of the facial artery. Saudi Medical Journal, 2006, vol. 27, n. 10, p. 1602. PMid:17013494.

NIRANJAN, NS. An anatomical study of the facial artery. Annals of Plastic Surgery, 1988, vol. 21, n. 1, p. 14-22. PMid:3421650. http://dx.doi.org/10.1097/00000637-198807000-00003

PARRETT, BM., PRZYLECKI, WH. and SINGER, MI. Reliability of the facial artery musculomucosal flap for intraoral reconstruction in patients who have undergone previous neck dissection and radiation therapy. Plastic and Reconstructive Surgery, 2012, vol. 130, n. 6, p. 910e-912e. PMid:23190857. http://dx.doi.org/10.1097/ PRS.0b013e31826dal43

PICCIONE, MJ., MANGANARO, AM. and ALMONY, JS. Caliber-persistent labial artery: diagnosis and treatment--case report. Journal of Oral and Maxillofacial Surgery, 2010, vol. 68, n. 8, p. 1987-1989. PMid:19954876. http://dx.doi.org/10.1016/j. joms.2009.05.433

PINAR, YA., BILGE, O. and GOVSA, F. Anatomic study of the blood supply of perioral region. Clinical Anatomy, 2005, vol. 18, n. 5, p. 330-339. PMid:15971214. http://dx.doi.org/10.1002/ ca. 20108

PRIBAZ, JJ., MEARA, JG., WRIGHT, S., SMITH, JD., STEPHENS, W. and BREUING, KH. Lip and vermilion reconstruction with the facial artery musculomucosal flap. Plastic and Reconstructive Surgery, 2000, vol. 105, n. 3, p. 864-872. PMid:10724244. http://dx.doi.org/10.1097/00006534200003000-00007 
RAYNER, CR. Oral mucosal flaps in midfacial reconstruction. British Journal of Plastic Surgery, 1984, vol. 37, n. 1, p. 43-47. http://dx.doi.org/10.1016/0007-1226(84)90039-0

STANDRING, S. Gray's Anatomy: The Anatomical Basis of Clinical Practice. 40th ed. Philadelphia: Churchill Livingstone, 2008.

TEZEL, E. Buccal Mucosal Flaps: A Review. Plastic and Reconstructive Surgery, 2002, vol. 109, n. 2, p. 735-741. PMid:11818861. http://dx.doi.org/10.1097/00006534200202000-00048
WEE, SS., HRUZA, GJ. and MUSTOE, TA. Refinements of nasalis myocutaneous flap. Annals of Plastic Surgery, 1990, vol. 25, n. 4, p. 271-278. PMid:2244736. http://dx.doi. org/10.1097/00000637-199010000-00005

XIE, L., LAVIGNE, F., RAHAL, A., MOUBAYED, SP. and AYAD, T. Facial artery musculomucosal flap for reconstruction of skull base defects: A cadaveric study. Laryngoscope, 2013. http://dx.doi. org/10.1002/lary.23939

Received February 26, 2013 Accepted February 15, 2014 